\title{
Listening in the paradigm of activity psycholinguistics
}

\author{
N. V. Kharchenko \\ SHEE "Pereyaslav-Khmelnytskyi State Pedagogical University named after Hryhoriy Skovoroda", \\ Corresponding author. E-mail:harchenko123@rambler.ru
}

Paper received 19.11.17; Revised 23.11.17; Accepted for publication 25.11.17.

https://doi.org/10.31174/SEND-HS2017-147V25-09

\begin{abstract}
The article deals with the phenomenon of listening from the standpoint of activity psycholinguistics. For this purpose were examined the fundamental theoretical positions of the classical psychological theory of activity, which reveals the specific features of the actions and operations of a listener. Psycholinguistic conceptions of listening, developed by L.S. Vyhotskyi, O.R. Luria, O.O. Leontiev, M.I. Zhynkin, O.M. Sokolov, O.O. Zalevskaya and other scholars are analyzed. Based on psycholinguistic conceptions, the author's interpretation of the term "listening" is formulated.
\end{abstract}

Keywords: listening, activity psycholinguistics, internal speech, meaning, sense.

Introduction. In psycholinguistic science, research works on listening are carried out within the framework of the main paradigms - gestaltivism, behaviorism, generative (generating) grammar, communicativism, connecticism, cognitive psycholinguistics, neuro psycholinguistics, and activity psycholinguistics. Within each of them a peculiar view on the nature and character of listening as a complex psycholinguistic phenomenon is revealed, the original conceptions and theories of listening are developed and substantiated, various models of speech perception and speech comprehension are presented. Recently, the attention of many foreign and national scholars is intensified to the activity psycholinguistics, which has a high "explanatory force" in the disclosure of multifaceted phenomenon of listening, as it is based on the basic conceptual positions of the classical psychological theory of activity that reveals the specifics of actions and operations of its subject (listener). Based on the almost universally accepted theories, psycholinguistics provides modern knowledge of the activity and processing character of speech perception and speech understanding, functional system of listening, the phase structure of speech activity, proactive reflection of reality, heuristic semantic interaction, and many other important aspects of a human speech thinking.

The purpose of the article is to present the results of the analysis concerning fundamental principles and concepts of the activity psycholinguistics, within which is characterized the complex and multidimensional phenomenon - listening.

Methods of the research. In this research were used theoretical methods, in particular: the analysis and generalization of psycholinguistic and psychological literature, formulation of the concept of "listening", systematization of the generalized data of theoretical part of the research, formulation of conclusions.

Research results. The activity psycholinguistic paradigm in study of listening is based on the conceptual provisions of psychological linguistics, which is considered to be the original source of the development of modern psycholinguistics as a scientific knowledge. Thus, the idea of activity approach to the phenomena of thought, language and speech, their close interconnection and functional unity, as well as to language as a condition of thinking belongs to $\mathrm{V}$. fon Humboldt. The scientist noted that "language is not a product of the activity, but the activity itself. <...> Language is a constant renewal of the spirit, aimed at making articulation sounds suitable for expressing a thought. This definition is also useful for any act of the speech activity. <...> Dividing of language into words and rules is only a dead product of scientific analysis" [4, p. 75]. The main point of scientific researches made by O.O. Potebnia consists in a statement that speech activity is significant for a person who learns the world through language and with the help of language. The object of scientist's researches was an individualpsychological speech act as a creative process for the part of the speaker and listener. According to O.O. Potebnia, speech is not a means of expressing the already ready thought, but for creating it. It (a language) is not a reflection of the outlook that has already been formed, but the activity that makes it [8, p. 171]. An interaction of language and thinking in speech activity is the central issue in the concept of a scientist, according to which, "language is a prerequisite for thinking" [9, p. 30]. In his studies, the scientist paid the particular attention to analyzing the speech comprehension process, expressing and arguing a number of conceptual provisions that remain important for our study. O.O. Potebnia became the first in psychological linguistics, which actualized the problem of speech understanding as a process of transforming values into individual semantic structures. The scientific heritage of I. A. Baudouin de Courtenay is "permeated" with the idea of integrative approach to the phenomena of language, speech and human thought activity. Language, in understanding of a scientist, is an integral part of the triune system of the phenomenon "thought-speechlanguage". In this complex language creation the scientist identified such characteristic features as nonlinearity, hierarchical character, dynamism, creative and heuristic character. Especially valuable for the development of modern psycholinguistic science is the proposed I.A. Baudouin de Courtenay position on the unconscious course and conscious management of speech processes [3]. This provision has become basal in further scientific researches and discussions on the development of speech in ontogenesis. L.V. Shcherba formulated the thesis on distinction between three aspects of speech phenomena, by singling out the speech activity (as a set of the processes of speaking and understanding), the linguistic system (vocabulary and grammar) and the linguistic mate- 
rial (texts, the totality of what is spoken and understood) [10]. This thesis was developed over the time into a scientific conception, which became an important foundation for the development of contemporary psycholinguistic studies concerning speech activity, problems of speech capture, language acquisition and speech comprehension.

Modern activity psycholinguistics is an integral part of psychological "theory of activity", developed in L.S. Vyhotskyi's scientific school, and later deepened and in generalized (completed) form presented in writings of his disciples, in particular O.M. Leontiev [6]. In accordance with this theory, activity is the molar unit of human individual existence, a holistic multileveled system; it meets the need but is always objectified in a motive; its main formative components are the goals and corresponding to them actions and operations, and, finally, those implementing the activity, psycho-physiological functions, which form its natural conditions and impose restrictions on its course, they often rebuilt in it and even generated by it [6, p. 9]. Thus, listening in activity psycholinguistics is considered from the perspective of the "activity frame" (O.O. Leontiev), the components of which are the motive, actions, operations (as means of action), settings and results (products of activity). Consequently, the audition, as a type of speech activity, is characterized by all the main features of psychological activity, such as: subject matter; motivation; purposefulness; hierarchical (vertical) organization, including the hierarchical organization of its units; the phase (horizontal) structure of activity (motive, purpose, internal speech, in which, according to a refined model of T.V. Akhutina, there are two stages: 1. - "the choice of linguistic values"; 2. - "the choice of senses" (is proposed in the reciprocal way to generation of speech order) [1, p. 135].

L.S. Vyhotskyi in the aspect of the psychological theory of activity considers listening as a speech and thinking activity. The scientist opposes attempts to analyze coherent speech thinking, dismembering it into separate elements, because, according to his deep conviction, "this method makes it impossible to study the internal relations between the thought and a word" [13, p. 15]. He notes: "Dividing of speech thinking into its components, alien one in relation to the other - to thought and a word - the researchers try later, by studying the pure properties of thinking, regardless from speech, and speech regardless from thinking, in order to present a connection between them as a purely external mechanical dependence between two different processes. <...> This way of a research is fruitless, because it does not give us the key to studying the actual internal relations between the thought and a word in the process of speech thinking and speech activity" [13, p. 14-15]. To the analysis of speech thinking "according to the elements" the psychologist contrasts the analysis of speech "according to the units". Under the "unit" L.S. Vyhotskyi understands such a product of analysis, which, in contrast to the elements, is characterized by all the properties inherent in the whole and which are further inseparable living parts of this unity [13, p. 18]. Such unit in the unity of speech phenomena and thinking L.S. Vyhotskyi calls the meaning of the word, which is "simultaneously a speech and intellectual phenomenon, $<\ldots>$ of the verbal thought or comprehended word, the unity of the word and thought" [13, p. 382]. Based on
L.S. Vyhotskyi's psycholinguistic positions, O.O. Leontiev stressed the need for the units of analysis (psycholinguistic units) to have the status of "speech operations", that is particularly from them the process of listening (perception and understanding of speech) was formed [5].

By revealing the dramatic relationship in a holistic speech process, L.S. Vyhotskyi notes: "If a thought is embodied in the word in external speech, then the word dies in internal speech, giving birth to a thought" $[13, \mathrm{p}$. 453]. Thus, in the structure of listening as a multileveled speech and thinking activity, the scientist distinguishes a "special chain" - internal speech - which he considers as a specific one according to psychological nature, peculiar to its structure and the way of functioning speech formation. An important role of the internal speech L.S. Vyhotskyi saw in the fact that particularly in the internal speech took place the complex transformational curtailment operations (in the process of speech comprehension) and the deployment of the idea (in the process of generating the statement), the transcoding of the perceived speech into the code of individual senses. Consequently, the process of speech understanding, according to L.S. Vyhotskyi, is not a mirror image of the process of constructing a separate statement or integral text, but it is always the transformation of this statement into abbreviated semantic schemes at the level of internal speech. Therefore, "understanding involves a reverse movement from the external plan of speech into the inner one" [13, p. 403]. The peculiarity of the internal speech L.S. Vyhotskyi perceived in its semantic structure "domination of the word sense over its meaning" [13, p. 444]. Such a scientific "vision" of the internal speech semantic structure allowed the scientist to approach the question of separation and correlation between the "meaning and "sense" as well as to describe the phenomenon of "sense infusion", which, according to the scholar, has a significant influence on understanding the content of a perceived speech (text). According to L.S. Vyhotskyi, the ability to understand lies in the necessity to "orient in a complex internal space, which can be called a system of relationships. In this establishment of the relationships, separation of the important thing, in facts and transition is located the process, which is usually called an understanding" [13].

Fundamental ideas of L.S. Vyhotskyi concerning functioning of the internal speech chain in listening were further developed in scientific researches of the famous scientists (B.G. Ananiev, T.V. Akhutina, B.F. Baiev, P.P. Blonskii, M.I. Zhynkin, O.O. Leontiev, O.R. Luria, O.I. Novikov, O.M. Sokolov, L.S. Tsvetkova etc.). Formulating the original, built on the ideas of L.S. Vyhotskyi conceptual approaches to the genetic sources of the internal speech and its development in ontogenesis, the researchers are united in the thought that internal speech and listening (semantic perception) are closely interconnected: listening is done with the help of an internal speech; internal speaking is a means of listening. Hence, the difficulties of listening that appear in the recipients (both adults and children), the scientists associate with underdevelopment of an internal speech.

Theory of activity by L.S. Vyhotskyi and theory of speech activity by O.M. Leontiev became the methodo- 
logical basis for further development by V.O. Artemov, M.I. Zhynkin O.O. Zalevskaya, O.I. Zimniaya,O.O. Leontiev, O.R. Luria, O.I. Novikov, O.M. Sokolov, A.S. Shtern and other scholars of theoretical approaches and concepts of listening. So, in "psycholinguistic concept of denotates" by M.I. Zhynkin listening is presented as a multileveled, hierarchically organized whole, in which the hierarchy of predicates occupies a central place. In the process of understanding speech utterance takes place the reconstruction of sense, its transferring to a universal-subjective code - the code of intelligence - into the model fragments of reality, reflected in the discourse. So appears a denotate message that corresponds to an act of understanding. During the comprehension of the message and transition from language expressions to denotates appear the primary supports to understanding. Among the isolated speech message denotations are selected those that allow the recipient to add something to the content of the accepted statement, that is, to combine them into a coherent, global representation. The interconnection search of denotates ends with formation of a dynamic concept as a comprehensive reflection of the speech fragment content by a listener [15]. The understanding of the text, according to the scientist, occurs at the level of denotates through comprehension by the recipient of the connections and relations reflected in the corresponding text, as well as on the basis of background and encyclopedic knowledge of the corresponding denotates (ibid.).

Such a scientific view on the nature of the course of listening has developed in his conception "the image of the content of text" O.O. Leontiev. According to the scientist, the essence of understanding is in building by the recipient of "the image of the content of text", the essential features of which are, firstly, dynamism, because "the image of the content of text do not, but happens, and only in the constant formation - its being»; and secondly, objectivity, because "the recipient operates from the beginning with what is behind the text; by the text - the world of events, situations, ideas, feelings, values - the real world that exists outside and before the text"; Thirdly, polyphony, expressed in the fact that "the multifaceted world, which stands by the text, is interpreted differently by the recipient, depending on the fact that he must see what purpose and with what settings he "see" into the text" [5, p. 142].

O.R. Luria represents decoding of a speech message as an active in its nature and complicated by structure process, which is implemented in three stages: begins with the perception of external, deployed speech, then goes into understanding the general meaning of the statement, and finally is the semantic decryption of the inner deep meaning - subtext. The process of decoding the meaning, and then understanding of sense of the text, as the scientist notes, is always realized in a certain context, simultaneously with the perception of holistic semantic segments, sometimes even understanding of a single word actually follows the perception of the whole semantic complexes. At the same time, a successful understanding of the perceived message involves knowledge of deep syntactic structures that are basal for each component of the statement. Thus, a full understanding of the speech message is possible in terms of transition from the external surface values to the internal deep meanings [7].

Activity approach to listening is presented also in O.M. Sokolov's conception of "semantic landmarks". According to the position of the author, the formation of dynamic concept perceived by hearing occurs as a result of analytical and syntactic processing of audio information. Such processing takes place on the basis of identification by the recipient of the system of "semantic landmarks" in the internal speech. "Semantic landmarks" act as mnemonic pillars in both sense formation and sense formulation [12].

According to O.I. Novikov's (1983) conception of understanding, perception of statement begins with recognition by a listener of separate words sound forms, with which the recipient connects the meaning of these words stored in his memory. Separation and specification of denotates occurs due to actualization of the subject- content experience of a listener. All genotypes in thinking activity are presented in subject- schematic code. The content of the perceived statement (text), reflected in linguistic signs, is successionally transformed into a simulcast scheme.

In psycholinguistic conception by V.O. Artemov "analysis through synthesis" is shown the idea that listening is grounded on a step by step synthesis of semantic content based on perceptual analysis and in parallel with it conducted content analysis of the speech chain. The process of listening is completed by identification of separate semantically significant components of speech, the establishment of semantic links between them and unification of them in a holistic semantic whole [2].

In conception of "semantic perception" by O.I. Zimniaya listening is presented as a perceptualthinking-mnemonic activity, aimed at "extracting" by a recipient of the common sense from the received message. Thus, the essence of semantic perception is sense formation [16]. The mechanism of semantic perception the scientist introduced as follows: on the basis of word identification is made a decision on a semantic chain (syntagma), that is, the proposal, then the decision is made on the connection between the semantic chains, and, finally, on the basis of generalization of the results of all this perceptive-speech work is singled out the "integral indivisible unit of understanding" - the general meaning of the accepted statement [16]. The psychological scheme of semantic perception is presented by the researcher as a system consisting of three levels: excitatory-motivational, analytical-synthetic and performing. The fundamental principles of the presented system are, firstly, the principle of determinism (the conditionality of the process of semantic perception of the past experience of the recipient); secondly, the principle of advanced reflection (probable forecasting, nomination of semantic hypothesis due to the past experience, situation of communication and the context of speech message); thirdly, the principle of dynamic curtailment (the deployment of a semantic hypothesis and curtailment of the results of its analysis to the general meaning of a perceived expression).

In conception of "key words"(L.M. Murzina \& A.S. Stern, 1991) listening acts as a result of compression of the received message and at the same time as a support for its semantic restoration. These keywords serve as a kind of minitext, organized like any text, linearly and 
hierarchically, that is, the keywords reflect the predicative semantic organization of the basic speech message.

"Meta-theory of understanding the text") by O.O. Zalevskaya is based on the idea of integrative approach to study the phenomenon of listening, the essence of which consist in the unity of the theory of mental processes and the concept of "living knowledge", according to which listening acts as one of the components of a complex dynamic system of interaction between "the body of the text" and "soul", a person and society, verbal and non-verbal, perceived and unconscious [14].

Conclusions. From the standpoint of activity psycholinguistics and basing on the fundamental theoretical positions of L.S. Vyhotskyi, O.O. Zalevskaya, I.O. Zimniaya, O.R. Luria, O.O. Leontiev, M.I. Zhynkin, O.M. Sokolov and other scholars, we define listening as a receptive, intrinsically active form of speech and thinking activity, the procedural nature of which consists in organic unity, simultaneous mnemonic perceptual and thinking interaction and active complex implementation: 1) auditory perception of the values of the system of language codes / forms that reflect reality; 2) distinction, decryption and preservation of them in a short-term memory; and also 3) understanding of the meaning of speech message, which ends by implementation of the internal speech mechanisms, in which takes place the decoding of "superficial" language forms values and transforming them into "deep" meanings through comprehension and rethinking reflected in the expression fragment of reality. The result of perceptual-cognitive-affective processing makes either the exact and complete decoding and reproduction by the recipient of the author's meaning, the design and creation of an individual sense, authentic to author's, or inaccurate and incomplete reproduction of the author's meaning and deployment of a counter-own-understanding, based on a multifaceted sensual and rational individual linguistic and auditive experience of the subject of this activity, formed under the influence of society.

\section{REFERENCES}

1. Ahutina, T. V. Nejrolingvisticheskij analiz dinamicheskoj afazii. O mekhanizmah postroeniya vyskazyvaniya [Neurolinguistic analysis of dynamic aphasia. On the mechanisms for constructing an utterance]. Moskva: Terevinf, 2002. 144 c. [in Russian].

2. Artemov V. A. Psihologiya obucheniya inostrannym yazykam [Psychology of teaching foreign languages]. Moskva: Prosveshchenie, 1969. $279 \mathrm{~s}$.

3. Boduehn de Kurteneh I.A. Izbrannye trudy po obshchemu yazykoznaniyu [Selected works on general linguistics]. V.I. Mjskva: AN SSSR, 1963. 385 s. [in Russian].

4. Gumboldt V. fon. Izbrannye trudy po yazykoznaniyu [Selected Works on Linguistics]. Moskva: Progress, 1984. 400 s. [in Russian].

5. Leontiev A.A. Osnovy psiholingvistiki [Fundamentals of psycholinguistics]. Moskva: Smysl, 1999. $287 \mathrm{~s}$.

6. Leontiev, A.N. Obshchee ponyatie o deyatelnosti [General concept of activities]. Osnovy teorii rechevoj deyatelnostiFundamentals of the theory of speech activity, (pp. 5-21). Moskva: Nauka, 1974. [in Russian].

7. Lurija, A.R. Jazyk $i$ soznanie [Language and consciousness]. In E.D. Homskoj (Ed.). Rostov n/D.: Izd-vo "Feniks". 1998 [in Russian].

8. Potebnya A.A. Ehstetika i poehtika [Aesthetics and poetics].

Moskva: Istkusstvo, 1976. 614 s. [in Russian].

9. Potebnya, A. A. (1999). Mysl i yazyk [Thought and language]. Moskva: Labirint, 1999. 267 s. [in Russian].

10. Shcherba, L.S. Yazykova sistema i rechevaya deyatelnost [Language system and speech activity]. Leningrad.: Nauka, 1974. 428 s.[in Russian].

11. Smirnov A. A. (1966). Problemy psihologii pamyati [Problems of the psychology of memory]. Moskva: Prosveschenie, 1966. 375 s. [in Russian].

12. Sokolov, A. N. Vnutrennyaya rech $i$ myishlenie [Internal speech and thinking]. Moskva: Prosveschenie, 1968 [in Russian].

13. Vygotsky, L. S. (2011). Myshlenie $i$ rech [Thinking and Speech]. Moskva: AST: Astrel, 2011. [in Russian].

14. Zalevskaja, A. A. Psiholingvisticheskie issledovanija. Slovo. Tekst: [Psycholinguistic researches. Word. Text]. Moskva: Gnozis, 2005 [in Russian].

15. Zhinkin, N. I. Rech kak provodnik informacii [Speech as a transformer of information]. Moskva: Nauka, 1982. [in Russian].

16. Zimniaya, I. A. Lingvopsihologija rechevoj dejatelnosti [Lingvopsychology of speech activity]. Moskva: Moskovskij psihologo-socialnyj institut, Voronezh: NPO "MODJeK", 2001 [in Russian].

\section{Аудирование в парадигме деятельностной психолингвистики}

\section{Н. В. Харченко}

Аннотация. В статье раскрыт феномен «аудирование» с позиции деятельной психолингвистики. С этой целью проанализированы фундаментальные теоретические положения классической психологической теории деятельности, которая раскрывает специфику действий и операций субъекта понимания; проанализированы психолингвистические концепции аудирования, разработанные Л.С. Выготским, А.Р. Лурией, А.А. Леонтьевым, Н.И. Жинкиным, А.Н. Соколовым, А.А. Залевской и другими учеными. С опорой на психолингвистические концепции, сформулировано авторское определение термина «аудирование».

Ключевые слова: аудирование, деятельностная психолингвистика, внутрення речь, значение, смысл. 